medRxiv preprint doi: https://doi.org/10.1101/2021.01.21.21250251; this version posted January 22, 2021. The copyright holder for this preprint (which was not certified by peer review) is the author/funder, who has granted medRxiv a license to display the preprint in perpetuity.

All rights reserved. No reuse allowed without permission.

\title{
Air passenger travel and international surveillance data predict spatiotemporal variation in measles importations to the United States
}

\author{
Marya L. Poterek ${ }^{1}$, Moritz U.G. Kraemer ${ }^{2,3,4}$, Alexander Watts ${ }^{5,6}$, Kamran Khan ${ }^{5,6,7}$, \\ T. Alex Perkins ${ }^{1}$ \\ ${ }^{1}$ Department of Biological Sciences and Eck Institute for Global Health, University of Notre Dame, \\ Notre Dame, IN, USA \\ ${ }^{2}$ Department of Zoology, University of Oxford, Oxford, UK \\ ${ }^{3}$ Harvard Medical School, Harvard University, Boston, MA, USA \\ ${ }^{4}$ Boston Children's Hospital, Boston, MA, USA \\ ${ }^{5}$ Li Ka Shing Knowledge Institute, St. Michael's Hospital, Toronto, Ontario, Canada \\ ${ }^{6}$ BlueDot, Toronto, Ontario, Canada \\ ${ }^{7}$ Department of Medicine, University of Toronto, Toronto, Ontario, Canada
}

\begin{abstract}
Measles incidence in the United States has grown dramatically, as vaccination rates are declining and transmission internationally is on the rise. Measles virus is highly infectious and can cause severe symptoms and even death. Because imported cases are necessary drivers of outbreaks in non-endemic settings, predicting measles outbreaks in the US depends on predicting imported cases. To assess the predictability of imported measles cases, we performed a regression of imported measles cases in the US against an inflow variable that combines air travel data with international measles surveillance data. To understand the contribution of each data type to these predictions, we repeated the regression analysis with alternative versions of the inflow variable that replaced each data type with averaged values and with versions of the inflow variable that used modeled inputs. We assessed the performance of these regression models using correlation, coverage probability, and area under the curve statistics, including with resampling and crossvalidation. Our regression model had good predictive ability with respect to the presence or absence of imported cases in a given state in a given year $(\mathrm{AUC}=0.78)$ and the magnitude of imported cases (Pearson correlation $=0.84$ ). By comparing alternative versions of the inflow variable averaging over different inputs, we found that both air travel data and international surveillance data contribute to the model's ability to predict numbers of imported cases, and individually contribute to its ability to predict the presence or absence of imported cases. Predicted sources of imported measles cases varied considerably across years and US states, depending on which countries had high measles activity in a given year. Our results emphasize the importance of the relationship between global connectedness and the spread of measles.
\end{abstract}


medRxiv preprint doi: https://doi.org/10.1101/2021.01.21.21250251; this version posted January 22, 2021. The copyright holder for this preprint (which was not certified by peer review) is the author/funder, who has granted medRxiv a license to display the preprint in perpetuity.

All rights reserved. No reuse allowed without permission.

\section{Introduction}

Despite the elimination of endemic measles in the United States in the 1990s, the number of measles cases and outbreaks has begun to rise in recent years, as measles-mumps-rubella (MMR) vaccination rates in the US are declining and transmission internationally is on the rise (1). Measles virus is highly infectious and can cause serious symptoms and even death, and cases imported to the US can result in outbreaks that harm vulnerable populations, particularly now as herd immunity wanes under the influence of anti-vaccine sentiment (2). Recent outbreaks have required significant public health responses and have led to stricter vaccination policies in some states (3).

Measles outbreaks often occur when infectious individuals enter into largely unvaccinated populations. This was the case in the 2019 New York outbreak, where several infected travelers carried measles into orthodox Jewish neighborhoods with low school immunization rates, resulting in hundreds of epidemiologically linked cases (4). Even a single infected traveler can spark a significant outbreak — a recent 71-case outbreak near Portland, Oregon was the result of a single international importation into an area with vaccination rates significantly lower than those required to maintain herd immunity $(3,5)$. Travelers such as these, carrying the measles virus internationally, pose a risk to susceptible individuals both while in transit and at their final destination, and are often the primary drivers of measles dynamics in non-endemic countries (6).

Many studies have acknowledged the importance of importation in both pre- and postelimination era US measles outbreaks $(7,8)$. This is inevitable while endemic measles remains present in many parts of the world. Ultimately, these importations are driven by a combination of 
medRxiv preprint doi: https://doi.org/10.1101/2021.01.21.21250251; this version posted January 22, 2021. The copyright holder for this preprint (which was not certified by peer review) is the author/funder, who has granted medRxiv a license to display the preprint in perpetuity.

All rights reserved. No reuse allowed without permission.

incidence in source countries and international travel patterns, suggesting that importation into the US will continue until elimination is achieved globally (9).

Patterns of imported cases have been modeled for many other diseases, including MERS, chikungunya, dengue, Zika, Ebola, Lassa fever, and COVID-19, and have focused on the relationship between air travel and importation risk (10-17). A previous implementation of travel-driven measles importation into New Zealand used travel data and global measles incidence data to determine age-specific importation risk with a generalized linear model (18). While existing studies have explored the relationship between international measles incidence, travel, and indices of importation risk, an understanding of how this relationship translates into actual imported case count predictions remains an outstanding question.

In this study, we used a regression model to make geographically specific predictions about the volume and likely origins of imported measles cases into the US, and incorporated reported imported cases that made validation of our predictions possible. Analysis of averaged values as modeled inputs allowed us to isolate the influence of passenger volume and international measles incidence on predictive performance; we additionally considered a null scenario in which state populations were substituted as input to the model. The inclusion of a variety of data types in this framework allowed us to model and explain spatial and temporal variation in measles importation patterns in the US.

\section{Methods}

Data

The Centers for Disease Control and Prevention (CDC) in the United States publishes annual reports of notifiable disease cases, including state-level case counts for both imported and 
medRxiv preprint doi: https://doi.org/10.1101/2021.01.21.21250251; this version posted January 22, 2021. The copyright holder for this preprint (which was not certified by peer review) is the author/funder, who has granted medRxiv a license to display the preprint in perpetuity.

All rights reserved. No reuse allowed without permission.

indigenous measles $(19,20)$. The CDC defines an imported case as one with a source outside the state, while an indigenous case must be unrelated to an imported case or occur more than two generations after a linked imported case (21). Though the former definition allows for both international and out-of-state origin cases to be designated as imported, there was insufficient detail present in the data to separate the two. Because the majority of recent reported measles outbreaks in the US have been specifically associated with international importation events, we made the simplifying assumption that all imported cases had an international origin $(22,23)$. As such, we included all reported imported and reported indigenous measles cases from 2011-2016 in this study.

The World Health Organization (WHO) provides open access to monthly surveillance reports for measles in member nations (24). We aggregated this data on an annual basis and used it in conjunction with United Nations (UN) annual population estimates to calculate yearly per capita measles incidence for member nations (25). We also considered an alternative set of assumptions about international surveillance data that seeks to correct for differential underreporting by country based on modeling (26), though open access data is available only by region, beginning in 2013 (27-30).

We obtained air passenger data from the International Air Transport Association (IATA) detailing monthly total passenger loads for flights from foreign countries to US states for the years 2011-2016 (31). We additionally considered an alternative set of assumptions about air passenger travel data based on open-access model predictions, to permit sharing of runnable code (32).

Model description 
For each year of the study, 2011-2016, we calculated an inflow variable representative of the movement of measles into a state, with New York and New Jersey combined due to their airports being shared extensively. We included all countries for which flight and incidence data was present, for a total of 189 countries and 50 states including Washington, D.C. Each state- and year-specific inflow was a summation of the per capita incidence in a country multiplied by the flux - i.e., the number of air passengers from that country to a given state - for all countries to that state in a given year, or

$$
\text { inflow }_{j, y}=\sum_{i} \text { flux }_{i j} \times \text { incidence }_{i}
$$

for all countries $i$ connected to state $j$ in year $y$. We performed a Poisson regression of imported measles cases, $I$, against this inflow variable such that

$$
I_{j, y} \sim \operatorname{Poisson}\left(\lambda \times \operatorname{inflow}_{j, y}\right)
$$

across all states $j$ and years $y$. Across all states and years, this implied that the likelihood of $\lambda$ was

$$
\operatorname{likelihood}(\lambda)=\prod_{j, y} \frac{\lambda^{I_{j, y}} e^{-\lambda}}{I_{j, y} !}
$$

which we used to estimate the value of $\lambda$ by maximum likelihood using the optimize function in $\mathrm{R}(33)$.

\section{Analyses}

To evaluate model performance, we used Pearson correlation, coverage probability of the $95 \%$ prediction interval, and area under the curve of the receiver operating characteristic curve (AUC). Correlation and coverage probability allowed us to assess the model's ability to account for variation in case numbers, whereas AUC allowed us to measure the model's performance as a classifier of whether states experienced imported cases in a given year. We used the pROC package to compare and analyze ROC curves (34). To quantify uncertainty for correlation and 
AUC, we sampled random subsets of $80 \%$ of the data 5,000 times, repeated the regression analysis, and recalculated these statistics based on the model's predictions of the remaining $20 \%$ of the data. This also served as a form of cross-validation, given that it quantified model performance on data withheld from model fitting.

\section{Alternative inflow variables}

To evaluate the contribution each data type made to predictive performance, we repeated the regression analysis using modified inflow variables that replaced each of the two data types with averaged values. The averaged values of international incidence were defined as average annual incidence weighted by total outgoing passenger counts, or

$$
\text { inflow }_{j, y}=\sum_{i} \text { flux }_{i j} \times\left(\frac{\sum_{i} \text { incidence }_{i} \times \sum_{j} \text { flux }_{i j}}{\sum_{i} \sum_{j} \text { flux }_{i j}}\right)_{y},
$$

such that the inflow variable for state $j$ and year $y$ was a summation of the product of each country-state flux and a single average incidence value for year $y$. The averaged passenger flow values were defined as the product of the total number of passengers into state $j$ and the proportion of passengers from country $i$ to all US states, for year $y$, or

$$
\text { inflow }_{j, y}=\sum_{i}\left(\sum_{i} \text { flux }_{i j} \times \frac{\sum_{j} \text { flux }_{i j}}{\sum_{i} \sum_{j} \text { flux }_{i j}} \times \text { incidence }_{i}\right) .
$$

We also considered a null inflow value in which inflow was replaced by state population, or

$$
\text { inflow }_{j, y}=\text { population }_{j, y}
$$

(35). Each alternative inflow variable was applied to Eqn. 2.

\section{Results}

Inflow variable informed by air travel and international surveillance data 
medRxiv preprint doi: https://doi.org/10.1101/2021.01.21.21250251; this version posted January 22, 2021. The copyright holder for this preprint (which was not certified by peer review) is the author/funder, who has granted medRxiv a license to display the preprint in perpetuity.

All rights reserved. No reuse allowed without permission.

We found that the inflow variable with full detail about air travel data and international surveillance data was associated with a high correlation between predicted and observed imported cases (0.84), which increased slightly when state-year combinations with zero imported cases were omitted (0.85) (Table 1). Likewise, we found that the 95\% prediction interval of this inflow variable had a coverage probability of $95 \%$, with data falling outside the prediction interval limited to state-year combinations with six or fewer imported cases (Figure 1A). With respect to predicting the presence of imported cases in a given state and year, the inflow variable with full detail had an AUC of 0.78. A similar AUC of $0.78 \pm 0.06$ was obtained through repetitive resampling and cross-validation, suggesting that predictions of the presence of imported cases were significantly better than at random (Table 2, Figure S1).

For reference, a model based on state population alone had a correlation of 0.66 and an AUC of 0.58 when fitted to the full data set (Table 1), and similar values in cross-validation (Table 2). Thus, while there was some predictive value associated with inflow based on state population alone, the addition of air travel and international surveillance data to the inflow variable resulted in a marked improvement in the ability to predict the presence and number of imported cases across states and years.

Table 1: Summary statistics including the fitted parameter $\lambda$, correlation between observed and predicted imported cases, and area under the receiver operating characteristic curve.

\begin{tabular}{|l|l|l|l|}
\hline Inflow variable & $\boldsymbol{\lambda}$ & Correlation & AUC \\
\hline Full detail & 0.041 & 0.84 & 0.78 \\
\hline Averaged incidence & 0.041 & 0.76 & 0.79 \\
\hline Averaged air travel & 0.041 & 0.76 & 0.79 \\
\hline Modeled incidence & 0.0022 & 0.77 & 0.79 \\
\hline Modeled flight data & 0.012 & 0.61 & 0.67 \\
\hline Population only & $4.32 \times 10^{-5}$ & 0.66 & 0.58 \\
\hline
\end{tabular}


medRxiv preprint doi: https://doi.org/10.1101/2021.01.21.21250251; this version posted January 22, 2021. The copyright holder for this preprint (which was not certified by peer review) is the author/funder, who has granted medRxiv a license to display the preprint in perpetuity.

All rights reserved. No reuse allowed without permission.

Table 2: Cross-validated summary statistics with uncertainty, including the fitted parameter $\lambda$, correlation between observed and predicted imported cases, and area under the receiver operating characteristic curve. Full distributions reflecting are shown in Figure S1.

\begin{tabular}{|l|l|l|l|}
\hline Inflow variable & $\begin{array}{l}\text { Cross-validated } \boldsymbol{\lambda} \\
(\mathbf{m e a n} \pm \mathbf{~ s d})\end{array}$ & $\begin{array}{l}\text { Cross-validated } \\
\text { correlation }(\mathbf{m e a n} \pm \mathbf{~ s d} \mathbf{s})\end{array}$ & $\begin{array}{l}\text { Cross-validated AUC } \\
(\mathbf{m e a n} \pm \mathbf{s d})\end{array}$ \\
\hline Full detail & $0.041 \pm 0.002$ & $0.78 \pm 0.2$ & $0.78 \pm 0.06$ \\
\hline Averaged incidence & $0.041 \pm 0.002$ & $0.71 \pm 0.2$ & $0.79 \pm 0.05$ \\
\hline Averaged air travel & $0.041 \pm 0.002$ & $0.71 \pm 0.2$ & $0.79 \pm 0.05$ \\
\hline Modeled incidence & $0.0022 \pm 1 \times 10^{-4}$ & $0.73 \pm 0.2$ & $0.79 \pm 0.06$ \\
\hline Modeled flight data & $0.012 \pm 9.3 \times 10^{-4}$ & $0.46 \pm 0.3$ & $0.67 \pm 0.07$ \\
\hline Population only & $4.32 \times 10^{-5}$ & $0.64 \pm 0.1$ & $0.58 \pm 0.03$ \\
\hline
\end{tabular}

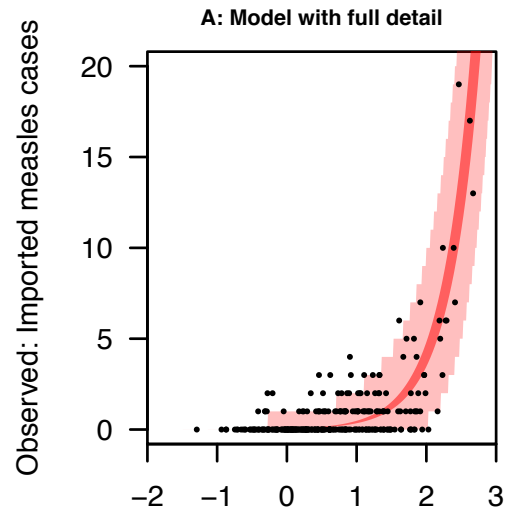

Predicted: $\log _{10}$ (inflow)

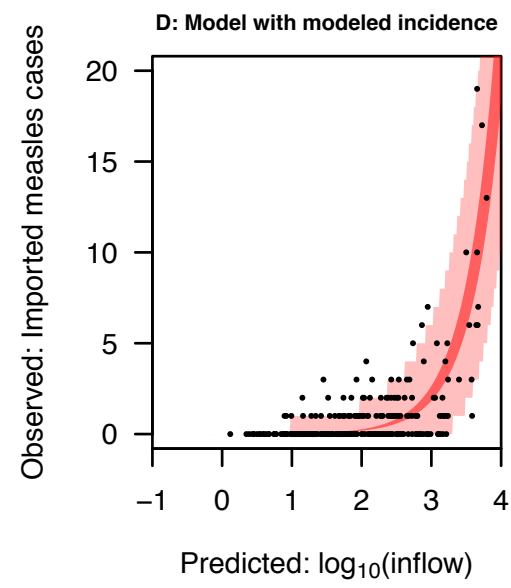

B: Model with averaged incidence

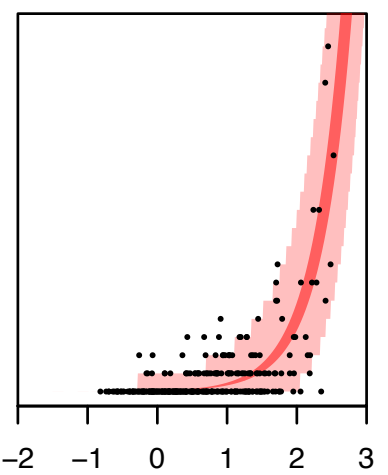

Predicted: $\log _{10}$ (inflow)

E: Model with modeled flight data

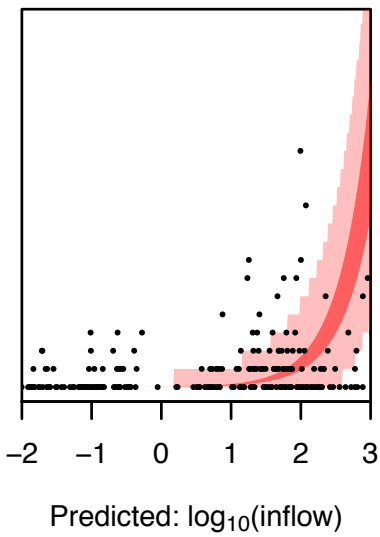

C: Model with averaged passengers

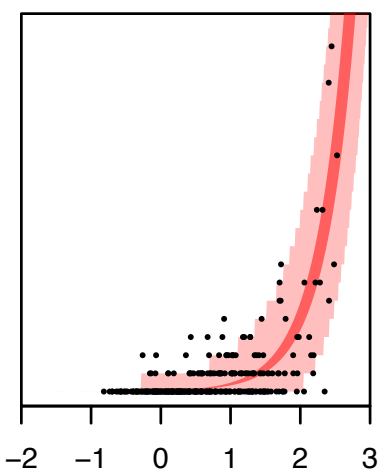

Predicted: $\log _{10}$ (inflow)

F: Model with population only

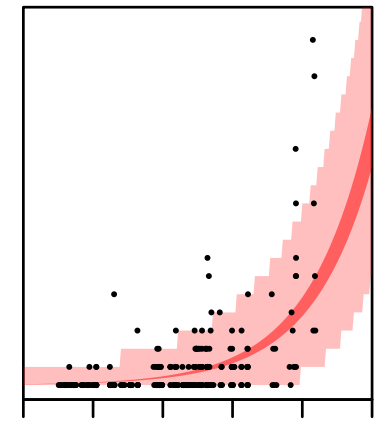

$\begin{array}{llllll}5.5 & 6.0 & 6.5 & 7.0 & 7.5 & 8.0\end{array}$

Predicted: $\log _{10}$ (population)

Figure 1: Observed imported measles cases accounted for by the fitted models. Black dots represent imported measles cases by state and year. The dark red band indicates the $95 \%$ confidence interval of the fitted relationship, while the light red band indicates the $95 \%$ prediction interval of the data. 
medRxiv preprint doi: https://doi.org/10.1101/2021.01.21.21250251; this version posted January 22, 2021. The copyright holder for this preprint (which was not certified by peer review) is the author/funder, who has granted medRxiv a license to display the preprint in perpetuity.

\section{Comparison with averaged inflow variables}

For the inflow variables that averaged over either air travel or international surveillance data, correlation was the statistic for which there was the greatest difference with the inflow variable with full detail. For both of these averaged inflow variables, correlation dropped from 0.84 to 0.76 (Table 1). This tendency held in cross-validation as well, with correlation dropping from 0.78 in the case of the inflow variable with full detail to $0.71 \pm 0.2$ for the averaged inflow variables (Table 2). In contrast, values of AUC associated with all three of these inflow variables were very similar (Table 1), including in cross-validation (Table 2). In terms of coverage of the prediction interval, the inflow variable with full detail captured $7 / 7$ state-year combinations with seven or more imported cases (Figure 1A), and inflow variables that averaged over one or the other data type both accounted for 6/7 (Figure 1, B and C). Thus, in some respects, there was a decrease in predictive performance when one data type was averaged, but retaining either data type still enabled reasonably good prediction of imported cases based on inflow.

\section{Comparison with modeled inflow variables}

Relative to the inflow variable with full detail, the inflow variable that used modeled international surveillance showed a drop in predictive performance. Its overall correlation was 0.77, its AUC was 0.79, and similar values were obtained in cross-validation (Tables 1, 2). Like the inflow variable with full detail, however, its prediction interval covered most observations (95\%), including those in which the highest numbers of imported cases were observed (Figure 1). Overall, predictions of imported cases based on modeled values of international surveillance performed similar to predictions based on the inflow variable with averaged values of raw international surveillance data, suggesting that the steps taken in generating modeled values 
medRxiv preprint doi: https://doi.org/10.1101/2021.01.21.21250251; this version posted January 22, 2021. The copyright holder for this preprint (which was not certified by peer review) is the author/funder, who has granted medRxiv a license to display the preprint in perpetuity.

All rights reserved. No reuse allowed without permission.

negatively impacted the predictive value of international surveillance for the purpose of predicting imported cases.

The inflow variable with modeled flight data performed worst among all the inflow variables that we evaluated. Its AUC was lower than all inflow variables except the null based on state population alone, and its overall correlation was lower than even that null inflow variable (Tables 1, 2). Also, a much larger proportion of observations (18\%) fell outside its 95\% prediction interval than under other inflow variables (Figure 1). Overall, predictions of imported cases based on modeled values of air travel were poor, and state population alone may offer an easier and more robust prediction of imported measles cases.

\section{Predicting measles origin and magnitude}

Using the inflow variable with full detail, we explored patterns in the predicted magnitude and potential origins of each state's imported cases from 2011 to 2016 (Figure 2). The expected number of imported cases was generally highest in the most populous states - notably, California, New York / New Jersey, Texas, Florida, and Illinois. In particular, California was predicted to have no fewer than 4.0 (95\% prediction interval: $0-9)$ imported cases in a single year (2012) and as many as 17.0 (95\% prediction interval: 8-29) (2014). Other than these six most populous states, most states were predicted to have fewer than two imported cases each year. This did vary by year, however, with one to three imported cases predicted for several states in 2011.

The estimated origins of imported cases also varied from year to year, and often correlated with trends in incidence in potential countries of origin (Figure 2). In 2011, imported cases were predicted to have been predominantly from France, which experienced a large 
medRxiv preprint doi: https://doi.org/10.1101/2021.01.21.21250251; this version posted January 22, 2021. The copyright holder for this preprint (which was not certified by peer review) is the author/funder, who has granted medRxiv a license to display the preprint in perpetuity.

All rights reserved. No reuse allowed without permission.

outbreak that year (36). In other years, other countries predominated - notably, the United Kingdom in 2012, the Philippines in 2014, and the Netherlands in 2016. In some cases, the predicted origins of imported measles cases varied among states. For example, in 2015 and 2016, a high proportion of the imported cases to Louisiana, Mississippi, and Texas were predicted to have originated in Equatorial Guinea, but much less so in other states. This resulted from a combination of high measles incidence in Equatorial Guinea in those years together with much higher levels of air travel between Equatorial Guinea and those states. 
2011

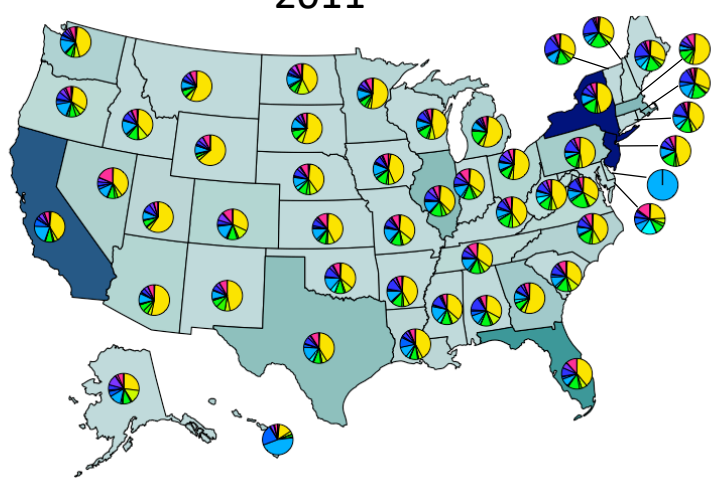

2013

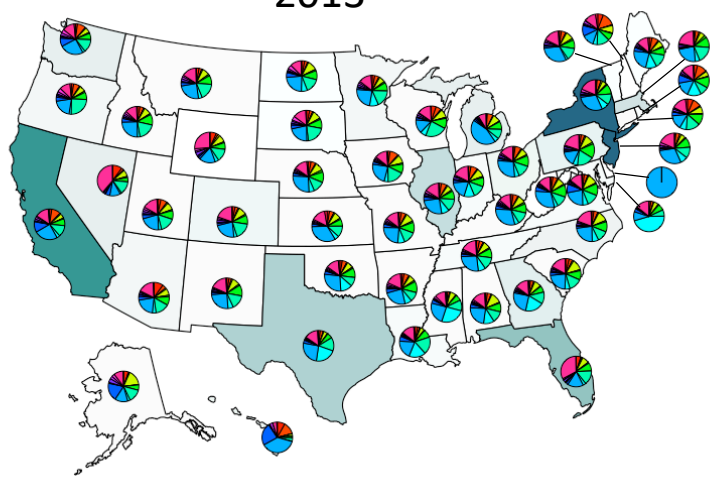

2015
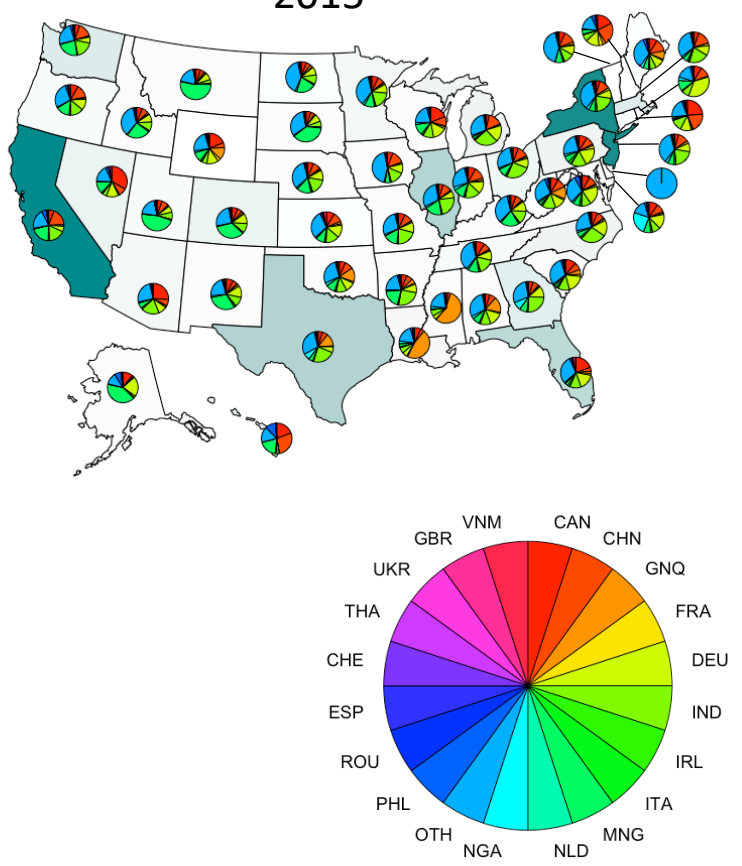

2012

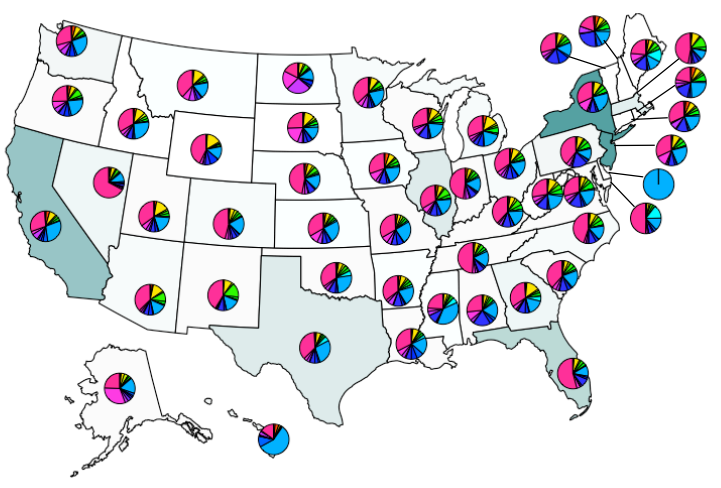

2014

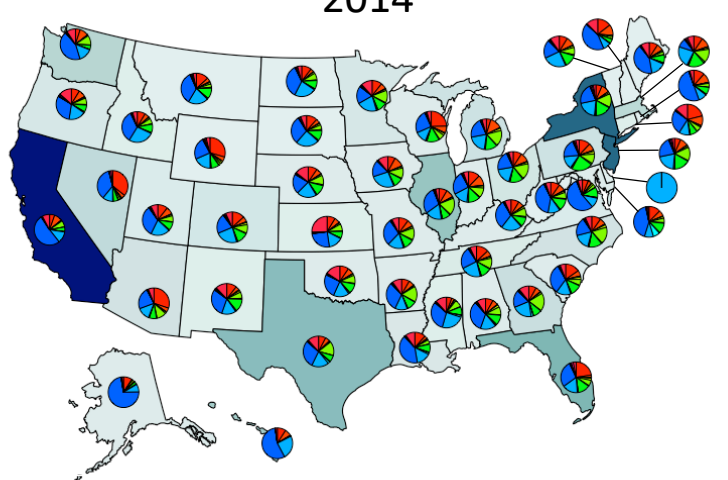

2016
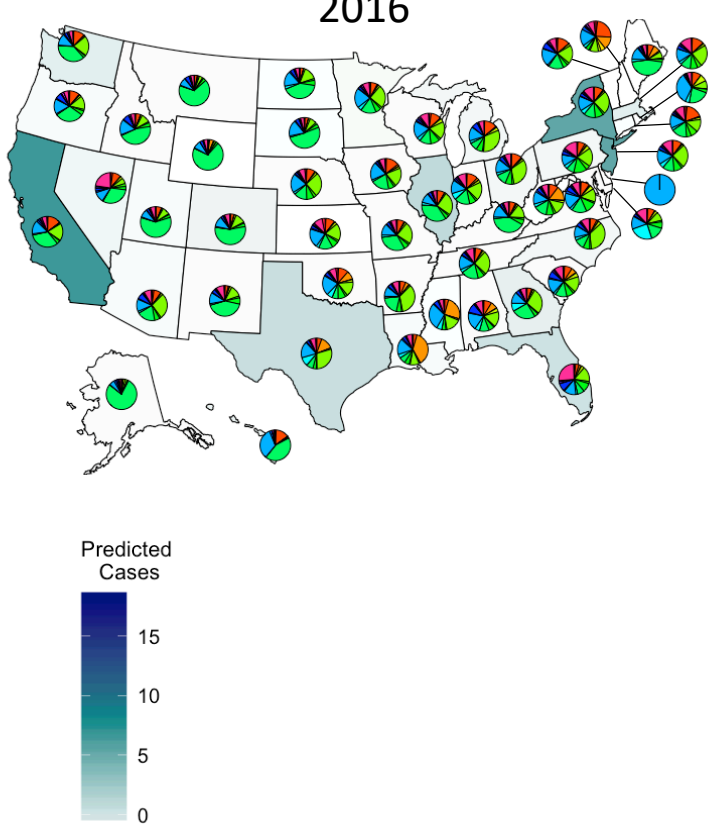

Figure 2: Predicted origins and magnitudes of measles importations into US states 2011 2016. Pie chart coloring indicates likely country of origin, while state fill color denotes magnitude of importation. As previously noted, New Jersey is grouped with New York, while Delaware has no major airport and is therefore marked as 'Other' throughout. 
medRxiv preprint doi: https://doi.org/10.1101/2021.01.21.21250251; this version posted January 22, 2021. The copyright holder for this preprint (which was not certified by peer review) is the author/funder, who has granted medRxiv a license to display the preprint in perpetuity.

All rights reserved. No reuse allowed without permission.

Association between imported and indigenous measles cases

Although our analysis focused on imported cases, we briefly explored the association between imported and indigenous cases to better understand the relevance of our analysis to measles outbreaks in the US. To do so, we calculated the Kendall rank correlation coefficient between imported and indigenous US measles cases combined across all years 2011-2016 and found a moderately large correlation of 0.45 that was statistically significant $\left(\mathrm{p}<2 \times 10^{-16}\right)$. While this suggests that local factors in the US, such as vaccination coverage, play an important role in determining the extent of indigenous measles cases in the US, so too do imported measles cases.

\section{Discussion}

Through regression of imported measles cases against multiple inflow variables, our analysis demonstrated the utility of air travel data and international surveillance data for predicting spatiotemporal variation in imported measles cases in the US. Cross-validation of these predictions verified their robustness, and comparison of predictions based on alternative inflow variables isolated the predictive value of alternative inputs for informing predictions of inflow. Inspection of our model's predictions with respect to state, year, and likely country of origin showed that predictions of imported cases in a given state and year depended on the state's population, the countries with which that state was linked via air travel, and contemporaneous measles activity in the countries with which it was most strongly linked.

A unique aspect of our analysis was the use of alternative inflow variables with different combinations of data inputs, which allowed us to isolate the effect of each data type on our predictions. Most of the inflow variables that we considered performed similarly well at 
medRxiv preprint doi: https://doi.org/10.1101/2021.01.21.21250251; this version posted January 22, 2021. The copyright holder for this preprint (which was not certified by peer review) is the author/funder, who has granted medRxiv a license to display the preprint in perpetuity.

All rights reserved. No reuse allowed without permission.

predicting the presence or absence of imported measles cases. There was greater discrepancy, however, in how well the inflow variables predicted the numbers of imported measles cases across states and years. Because each regression that we performed involved estimation of only a single parameter, these differences can be directly attributed to the data inputs. Comparison of predictions based on the inflow variable with full detail and those based on inflow variables with averaged inputs showed that air travel data and international surveillance data contributed roughly equally to the success of the model's predictions. In other words, each data type added some value on its own, but the two data types performed best when paired together.

Substituting either data input for a model-based alternative also reduced the quality of our predictions. In the case of modeled international surveillance, poorer performance could reflect that model-based revisions of measles burden work well for estimating burden within those countries (37) but less well for characterizing measles burden among the subset of the population likely to travel to the US $(38,39)$. In the case of modeled air travel, possible limitations include omission of airports below a certain size and the inability to pick up on idiosyncratic connections (32), such as the strong connection between Equatorial Guinea and states in the western Gulf Coast of the US — which could be related to the energy industry (40) — that emerged in our exploration of the possible country of origin of imported cases. In the era of COVID-19, air travel patterns are likely to continue to depart from historical trends $(41,42)$, providing further impetus for working with non-modeled air travel data appropriate to the time frame of interest.

Previous studies have identified air travel as a major driver of the importation of measles and a variety of other infectious diseases and have found value in incorporating reported imported case data $(11,12,18)$. By isolating air travel and incidence in model inputs, we were able to additionally explore the influence of each on measles importations events, as well as 
medRxiv preprint doi: https://doi.org/10.1101/2021.01.21.21250251; this version posted January 22, 2021. The copyright holder for this preprint (which was not certified by peer review) is the author/funder, who has granted medRxiv a license to display the preprint in perpetuity.

All rights reserved. No reuse allowed without permission.

leverage reported imported measles data to strengthen our approach via cross-validation.

Reported imported case data also allowed us to make and validate predictions regarding specific case counts. As a result, we developed a more detailed picture of imported measles dynamics in the US than might be possible without reported case data and facilitated an understanding of its drivers that might help inform mitigation strategies and interventions such as targeted travel screenings.

Although our analysis yielded predictions that appear to explain a moderate degree of variation in imported measles cases across states and years, there are limitations of our analysis that should be acknowledged. First, our travel data were limited to air passenger travel data only and did not include potential instances of importation by land or water. Measles outbreaks on cruise ships could be one overlooked source of importation $(43,44)$. This data constraint also affects which potential importers can be accounted for, as international air travel is expensive. To the extent that individuals with reduced access to vaccines are less likely to travel internationally, the usefulness of measles incidence data for predicting imported cases could be limited. Second, the quality of the international measles data used is limited by the strength of reporting countries' surveillance programs. Countries with poorer vaccination programs and more measles cases tend to have weaker surveillance systems, leading to underreporting. Though these countries are not necessarily highly connected to the US via air travel, such underreporting could nonetheless be present in model inputs. Third, our analysis was limited to imported case data that the CDC has made publicly available. Lack of data with which to validate estimates of country of origin limited our ability to draw conclusions about a causal relationship between model inputs and predicted case origins. Another study (45) was able to make use of more detailed information about imported case origin and month of detection held internally by the US CDC, which 
medRxiv preprint doi: https://doi.org/10.1101/2021.01.21.21250251; this version posted January 22, 2021. The copyright holder for this preprint (which was not certified by peer review) is the author/funder, who has granted medRxiv a license to display the preprint in perpetuity.

All rights reserved. No reuse allowed without permission.

enabled monthly predictions of imported case magnitude and origin that we were unable to produce. Although it would be ideal to perform our analysis and share results in real time, the data necessary to implement such an analysis are not readily available. Other recent studies have overcome this obstacle by leveraging historical surveillance data, along with air travel data and vaccination exemption rates, to generate predictions of measles outbreak risk in the US (46).

At a time when measles cases are on the rise, the capability to predict the origin and magnitude of imported cases is a worthwhile endeavor that could potentially inform surveillance and prevention strategies. Although our models cannot determine the exact provenance of measles cases, the framework developed here provides a mechanism for explaining broader variation in patterns of imported measles cases in the US that could be validated with alternative data, such as sequence analysis. Given that the US CDC's measles case definition states that "any case that cannot be proven as imported...[to] be classified as indigenous" (21), some imported cases may be misclassified as indigenous. The capability that we advance here to generate quantitative predictions of imported cases could be useful in analyses that seek to more carefully disentangle importation and local transmission. The relationship between importation and local transmission can be complicated (47), and much remains to be understood about the interplay between measles importation patterns and local drivers of local measles outbreaks. Predictive models of imported cases such as ours stand to play an important role in better understanding these dynamics.

\section{Acknowledgements}

MLP was supported by a Summer Undergraduate Research Fellowship and a Richard and Peggy Notebaert Premier Fellowship from the University of Notre Dame. 
medRxiv preprint doi: https://doi.org/10.1101/2021.01.21.21250251; this version posted January 22, 2021. The copyright holder for this preprint

(which was not certified by peer review) is the author/funder, who has granted medRxiv a license to display the preprint in perpetuity.

All rights reserved. No reuse allowed without permission.

\section{References}

1. Gastañaduy PA, editor. Assessment of the Status of Measles Elimination in the United States, 2001-2014. American Journal of Epidemiology. 2017;562-569.

2. Papania MJ, Wallace GS, Rota PA, Icenogle JP, Fiebelkorn AP, Armstrong GL, et al. Elimination of endemic measles, rubella, and congenital rubella syndrome from the Western hemisphere: the US experience. JAMA Pediatr. 2014 Feb;168(2):148-55.

3. Otterman S. Get Vaccinated or Leave School: 26,000 N.Y. Children Face a Choice. The New York Times Company [Internet]. 2019 Sep 6; Available from: https://www.nytimes.com/2019/09/03/nyregion/measles-vaccine-exemptions-ny.html.

4. McDonald R, Ruppert PS, Souto M. Notes from the Field: Measles Outbreaks from Imported Cases in Orthodox Jewish Communities - New York and New Jersey, 20182019. MMWR Morb Mortal Wkly Rep [Internet]. 2019 [cited 2020 Aug 10];68. Available from: https:/www.cdc.gov/mmwr/volumes/68/wr/mm6819a4.htm

5. Measles Investigation. Clark County Public Health [Internet]. 2019. Available from: https://www.clark.wa.gov/public-health/measles-investigation.

6. Grobusch M, P M, Rodriguez-Morales AJ, Wilson ME. Measles on the move. Travel Medicine and Infectious Disease. 2017;1-2.

7. Lee AD, Clemmons NS, Patel M, Gastañaduy PA. International Importations of Measles Virus into the United States During the Postelimination Era, 2001-2016. J Infect Dis. 2019 Apr 19;219(10):1616-23.

8. Oster NV, Harpaz R, Redd SB, Papania MJ. International Importations of Measles VirusUnited States, 1993-2001. The Journal of Infectious Diseases. 2004;48- 53.

9. Fiebelkorn AP, Redd SB, Gallagher K, Rota PA, Rota J, Bellini W, et al. Measles in the United States during the Postelimination Era. J Infect Dis. 2010 Nov 15;202(10):1520-8.

10. Nah K, Otsuki S, Chowell G, Nishiura H. Predicting the international spread of Middle East respiratory syndrome (MERS). BMC Infectious Diseases. 2016 Jul 22;16(1):356.

11. Findlater A, Moineddin R, Kain D, Yang J, Wang X, Lai S, et al. The use of air travel data for predicting dengue importation to China: A modelling study. Travel Medicine and Infectious Disease. 2019 Jul 5;101446.

12. Khan K, Bogoch I, Brownstein JS, Miniota J, Nicolucci A, Hu W, et al. Assessing the Origin of and Potential for International Spread of Chikungunya Virus from the Caribbean. PLoS Curr [Internet]. 2014 Jun 6 [cited 2019 Sep 12]; Available from: index.html\%3Fp=29473.html

13. Huang X, Hu W, Yakob L, Devine GJ, McGraw EA, Jansen CC, et al. El Niño Southern Oscillation, overseas arrivals and imported chikungunya cases in Australia: A time series analysis. PLoS Negl Trop Dis. 2019;13(5):e0007376. 
medRxiv preprint doi: https://doi.org/10.1101/2021.01.21.21250251; this version posted January 22, 2021. The copyright holder for this preprint

(which was not certified by peer review) is the author/funder, who has granted medRxiv a license to display the preprint in perpetuity.

All rights reserved. No reuse allowed without permission.

14. Candido DDS, Watts A, Abade L, Kraemer MUG, Pybus OG, Croda J, et al. Routes for COVID-19 importation in Brazil. J Travel Med [Internet]. 2020 May 18 [cited 2020 Aug 26];27(3). Available from: https://academic.oup.com/jtm/article/27/3/taaa042/5809508

15. Massad E, Tan S-H, Khan K, Wilder-Smith A. Estimated Zika virus importations to Europe by travellers from Brazil. Global Health Action. 2016 Dec 1;9(1):31669.

16. Tuite AR, Watts AG, Khan K, Bogoch II. Ebola virus outbreak in North Kivu and Ituri provinces, Democratic Republic of Congo, and the potential for further transmission through commercial air travel. J Travel Med [Internet]. 2019 Oct 14 [cited 2020 Aug 26];26(7). Available from: https://academic.oup.com/jtm/article/26/7/taz063/5550274

17. Tuite AR, Watts AG, Kraemer MUG, Khan K, Bogoch II. Potential for Seasonal Lassa Fever Case Exportation from Nigeria. The American Journal of Tropical Medicine and Hygiene. 2019 Mar 6;100(3):647-51.

18. Hayman DTS, Marshall JC, French NP, Carpenter TE, Roberts MG, Kiedrzynski T. Global importation and population risk factors for measles in New Zealand: a case study for highly immunized populations. Epidemiol Infect. 2017 Jul;145(9):1875-85.

19. Nationally Notifiable Infectious Diseases and Conditions, United States: Annual Tables. Centers for Disease Control and Prevention [Internet]. 2018. Available from: https://wonder.cdc.gov/nndss/nndss_annual_tables_menu.asp.

20. Morbidity and Mortality Weekly Report: Summary of Notifiable Infectious Diseases. Centers for Disease Control and Prevention [Internet]. 2018. Available from: https://www.cdc.gov/mmwr/mmwr_nd/index.html.

21. Classification of Measles Cases and Categorization of Measles Elimination Programs. Morbidity and Mortality Weekly Report. 1983;707-711.

22. Sanyaolu A, Okorie C, Marinkovic A, Ayodele O, Abbasi AF, Prakash S, et al. Measles Outbreak in Unvaccinated and Partially Vaccinated Children and Adults in the United States and Canada (2018-2019): A Narrative Review of Cases. Inquiry [Internet]. 2019 Dec 11 [cited 2020 Aug 10];56. Available from: https://www.ncbi.nlm.nih.gov/pmc/articles/PMC6906342/

23. Taylor EM, Burke H, Zhou W. Crossing Borders: One World, Global Health. Clinical Infectious Diseases. 2012;

24. World Health Organization. Provisional monthly measles and rubella data [Internet]. [cited 2019 May 15]. Available from: https://www.who.int/teams/immunization-vaccines-andbiologicals/immunization-analysis-and-insights/surveillance/monitoring/provisionalmonthly-measles-and-rubella-data

25. United Nations Department of Economic and Social Affairs. World Population Prospects [Internet]. 2018. Available from: https://population.un.org/wpp/Download/Standard/Population/. 
medRxiv preprint doi: https://doi.org/10.1101/2021.01.21.21250251; this version posted January 22, 2021. The copyright holder for this preprint (which was not certified by peer review) is the author/funder, who has granted medRxiv a license to display the preprint in perpetuity. All rights reserved. No reuse allowed without permission.

26. Simons E, Ferrari M, Fricks J, Wannemuehler K, Anand A, Burton A, et al. Assessment of the 2010 global measles mortality reduction goal: results from a model of surveillance data. The Lancet. 2012 Jun 9;379(9832):2173-8.

27. Perry RT, Gacic-Dobo M, Dabbagh A, Mulders MN, Strebel PM, Okwo-Bele J-M, et al. Progress Toward Regional Measles Elimination - Worldwide, 2000-2013. MMWR Morbidity and Mortality Weekly Report. 2014;63(45):1034-8.

28. Perry RT, Murray JS, Gacic-Dobo M, Dabbagh A, Mulders MN, Strebel PM, et al. Progress Toward Regional Measles Elimination - Worldwide, 2000-2014. MMWR Morbidity and Mortality Weekly Report. 2015;64(44):1246-51.

29. Patel MK, Gacic-Dobo M, Strebel PM, Dabbagh A, Mulders MN, Okwo-Bele J-M, et al. Progress Toward Regional Measles Elimination - Worldwide, 2000-2015. MMWR Morb Mortal Wkly Rep. 2016;65(44):1228-33.

30. Dabbagh A, Patel, Minal K., Dumolard L, Gacic-Dobo M, Mulders MN, Okwo-Bele J-M, et al. Progress Toward Regional Measles Elimination - Worldwide, 2000-2016. MMWR Morb Mortal Wkly Rep. 2017;66(42):1148-53.

31. International Air Transport Association. iata.org [Internet]. 2018. Available from: https://www.iata.org.

32. Mao L, Wu X, Huang Z, Tatem AJ. Modeling monthly flows of global air travel passengers: an open-access data resources. Journal of Transport Geography. 2015;52-60.

33. Team RC. R: A language and environment for statistical computing. R Foundation for Statistical Computing [Internet]. Available from: https://www.R-project.org/.

34. Robin X, Turck N, Hainard A, Tiberti N, Lisacek F, Sanches J-C, et al. pROC: an opensource package for $\mathrm{R}$ and $\mathrm{S}+$ to analyze and compare ROC curves. BMC Bioinformatics. 2011;77.

35. State Population Totals and Components of Change: 2010-2019. United States Census Bureau [Internet]. 2018. Available from: https://www.census.gov/data/tables/timeseries/demo/popest/2010s-state-total.html\#par_textimage_1574439295.

36. Huoi C, Casalegno JS, Bénet T, Neuraz A, Billaud G, Eibach D, et al. A report on the large measles outbreak in Lyon, France, 2010 to 2011. Eurosurveillance. 2012 Sep 6;17(36):20264.

37. Chen S, Fricks J, Ferrari MJ. Tracking measles infection through non-linear state space models. Journal of the Royal Statistical Society: Series C (Applied Statistics). 2012;61(1):117-34.

38. Muscat M. Who Gets Measles in Europe? J Infect Dis. 2011 Jul 1;204(suppl_1):S353-65. 
medRxiv preprint doi: https://doi.org/10.1101/2021.01.21.21250251; this version posted January 22, 2021. The copyright holder for this preprint

(which was not certified by peer review) is the author/funder, who has granted medRxiv a license to display the preprint in perpetuity.

All rights reserved. No reuse allowed without permission.

39. Bednarczyk RA, Rebolledo PA, Omer SB. Assessment of the role of international travel and unauthorized immigration on measles importation to the United States. J Travel Med [Internet]. 2016 May 1 [cited 2020 Sep 16];23(3). Available from: https://academic.oup.com/jtm/article/23/3/taw019/2580719

40. Equatorial Guinea Operations [Internet]. Marathon Oil. [cited 2020 Sep 16]. Available from: https://www.marathonoil.com/operations/eg/

41. Full article: Pandemics, tourism and global change: a rapid assessment of COVID-19 [Internet]. [cited 2020 Sep 16]. Available from: https://www.tandfonline.com/doi/full/10.1080/09669582.2020.1758708

42. Tuite AR, Bhatia D, Moineddin R, Bogoch II, Watts AG, Khan K. Global trends in air travel: implications for connectivity and resilience to infectious disease threats. J Travel Med [Internet]. $2020 \mathrm{Jul} 14$ [cited 2020 Sep 16];27(4). Available from: https://academic.oup.com/jtm/article/27/4/taaa070/5831125

43. Mitruka K, Felsen CB, Tomianovic D, Inman B, Street K, Yambor P, et al. Measles, Rubella, and Varicella Among the Crew of a Cruise Ship Sailing From Florida, United States, 2006. J Travel Med. 2012 Jul 1;19(4):233-7.

44. Victor D. Measles on Cruise Ship Leads to Quarantine in St. Lucia. The New York Times [Internet]. 2019 May 2; Available from:

https:/www.nytimes.com/2019/05/02/world/americas/measles-scientology-cruiseship.html.

45. Truelove SA, Mier-y-Teran-Romero L, Gastanaduy P, Walker AT, Berro A, Lessler J, et al. Epidemics, Air Travel, and Elimination in a Globalized World: The Case of Measles. medRxiv. 2020 May 12;2020.05.08.20095414.

46. Sarkar S, Zlojutro A, Khan K, Gardner L. Measles resurgence in the USA: how international travel compounds vaccine resistance. The Lancet Infectious Diseases. 2019 Jul $1 ; 19(7): 684-6$.

47. Oidtman RJ, Lai S, Huang Z, Yang J, Siraj AS, Reiner RC, et al. Inter-annual variation in seasonal dengue epidemics driven by multiple interacting factors in Guangzhou, China. Nat Commun. 2019 Mar 8;10(1):1-12.

\section{Supplement}



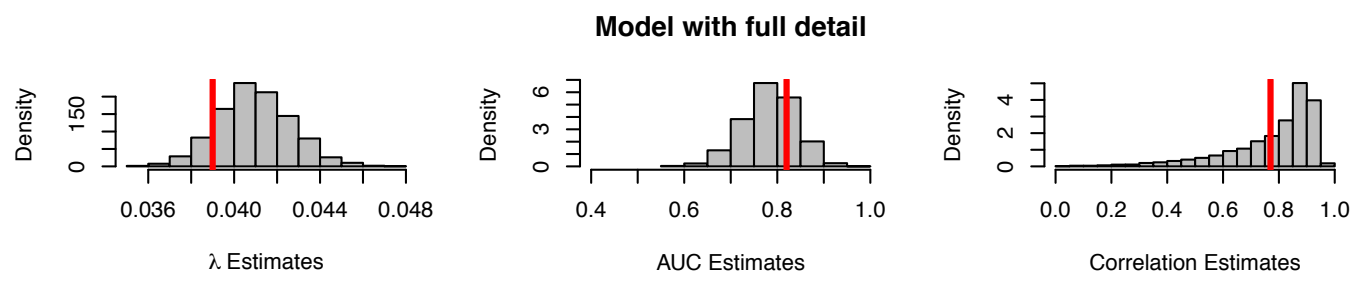

Model with averaged incidence
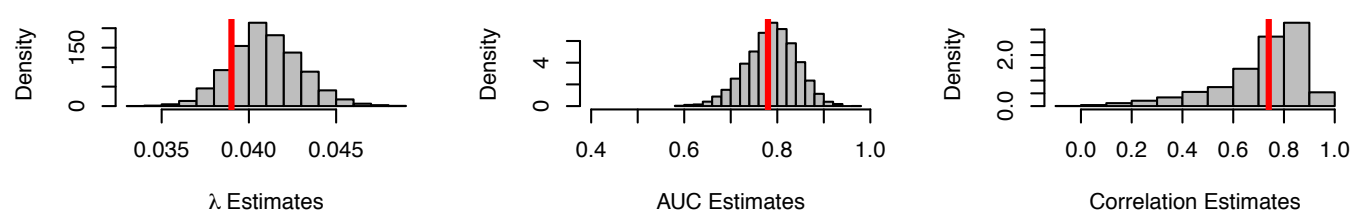

Model with averaged air travel
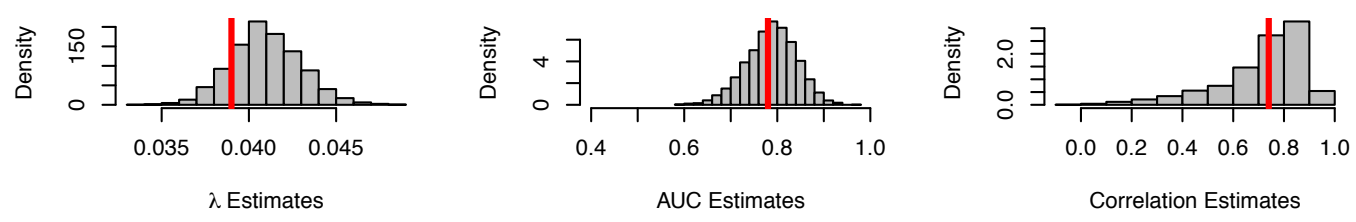

Model with modeled incidence
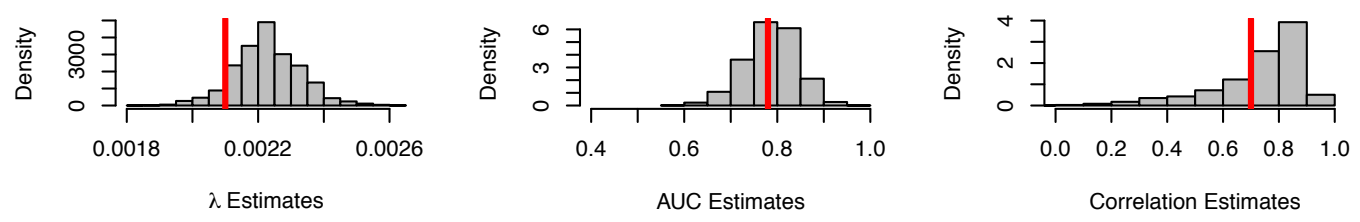

Model with modeled flight data
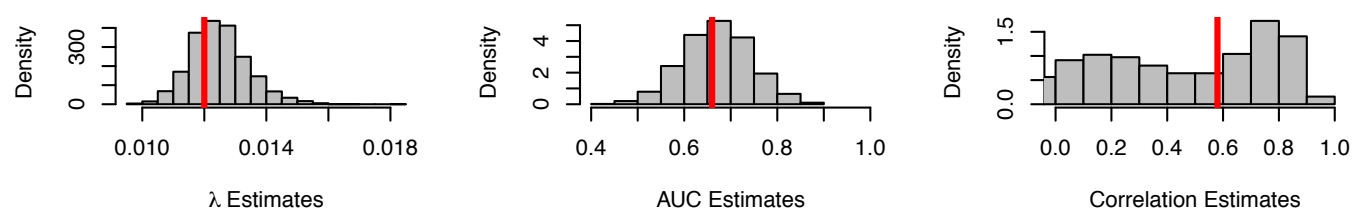

\section{Model with population only}

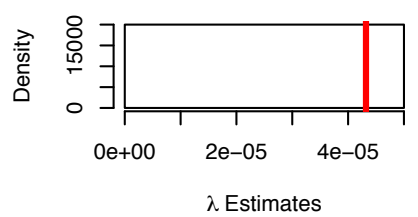

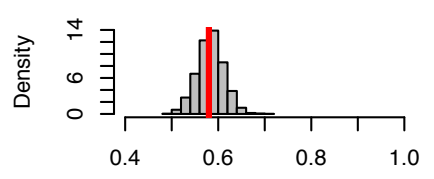

AUC Estimates

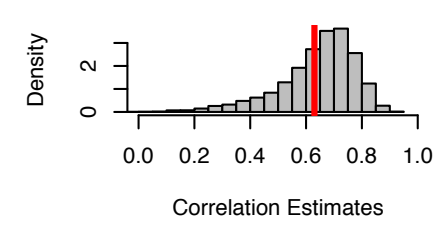

Figure S1: Histograms of partial fit model statistics. Values generated when each model was fit to the complete dataset are shown in red. The null model's resampling process consistently generated identical $\lambda$, likely a result of the large population values in question, and as a result no histogram is shown. 